\title{
An Analysis of Financial Performance on Non-bank Financial Institutions (NBFI) in Bangladesh: A Study on Lanka-Bangla Finance Limited
}

\author{
Raad Mozib Lalon, Sameer Hussain \\ Department of Banking \& Insurance, Faculty of Business Studies, University of Dhaka, Dhaka, Bangladesh \\ Email address: \\ raadmozib@du.ac.bd (R. M. Lalon), mozib.banking@gmail.com (S. Hussain)
}

To cite this article:

Raad Mozib Lalon, Sameer Hussain. An Analysis of Financial Performance on Non-Bank Financial Institutions (NBFI) in Bangladesh: A Study on Lanka-Bangla Finance Limited. International Journal of Economics, Finance and Management Sciences.

Vol. 5, No. 5, 2017, pp. 251-262. doi: 10.11648/j.ijefm.20170505.14

Received: July 16, 2017; Accepted: July 27, 2017; Published: September 26, 2017

\begin{abstract}
This paper is designed to divulge the financial performance of a selective non-bank financial institutions operating in Bangladesh using the ratio analysis of Lanka Bangla Finance Limited. Lanka Bangla Finance Limited is one of the best nonbanking financial institutions in Bangladesh. It has become possible due to its proper usage of its resources. In this paper we will be able to find out how they have managed their assets to cover their liabilities. This report will also show why the ratio analysis is so important of a company. To conduct the study, we have collected secondary data from LBFL. This paper is solely based on the ratio analysis segmented in following four broad categories such as Liquidity Ratio, Solvency Ratio, Profitability Ratio and Market Prospect Ratio. We have accumulated in total of 17 ratios included in these four broad categories.
\end{abstract}

Keywords: ROE, ROA, LBFL, ROCE, Du Point, Profit Margin, Equity Multiplier, NBFI

\section{Introduction}

There are more than 200 companies are listed in the Dhaka stock exchange of Bangladesh. All of them are not in the same position or all of them are not in the same category, but it is difficult for the general investors to find out which company is in better position \& which company is not. The best way to find out is the analysis of the financial statements of the company. One of the most useful \& well practiced ways of analysing the financial statement is the ratio analysis. In our study I have tried to provide a ratio analysis of Lanka Bangla Finance Limited. Ratios will be provided in the four broad categories. In this study there shall be several problems that will be found out $\&$ the relevant solutions shall be provided. Overall our study is to provide a detail ratio analysis of Lanka Bangla Finance Limited with findings \& recommendation.

\section{Objectives of the Study}

The objectives of the study are:

(a) To know the current position of Lanka Bangla Finance Limited. (b) To analyse different ratios of the company.

(c) To analyse the financial highlights of the company.

(d) To understand how the company have managed its assets \& liabilities.

(e) To find out the overall position of the company from the ratio analysis.

To know the history \& profile of Lanka Bangla Finance Limited.

\section{Methodology}

This study includes both descriptive part \& analysis part. This study will require some of the data that are not primary. Because in this type of business primary data is not available $\&$ if available they will take huge time to study.

\subsection{Types of Data}

To conduct the study I will utilize the secondary sources of data as mentioned below:

(a) Annual reports of Lanka Bangla Finance Limited.

(b) Website of LBFL.

(c) Different annual published material of Bangladesh Bank. 


\subsection{Data Analysis Tools}

After collecting the data, I will conduct ratio analysis using different ratios as stated below:

(a) Earnings Per Share

(b) Price earnings Ratio.

(c) Return on Asset.

(d) Debt to equity.

(e) Debt ratio.

(f) Return on equity.

(g) Basic earning power ratio.

\section{Financial Performance Analysis}

Financial ratios are mathematical comparison of different components of financial statements. These ratios help investors; creditors \& company management to understand how well the company is performing $\&$ what are the areas of improvement. Financial ratios are the most commonly used tool for analyzing the position of a business. Ratios can also be used to analyze the position \& comparison between different companies from different industries. Ratios do not take into consideration the size of the company. In our study on Lanka Bangla Finance Limited, we have divided the ratios into several categories:

(a) Liquidity Ratio.

(b) Solvency Ratio or Financial Leverage Ratio.

(c) Profitability Ratio.

(d) Market Prospect Ratio.

Other than these four broad categories we have also included several other ratios.

\subsection{Liquidity Ratios}

Liquidity ratios show a company's ability to pay off the current liabilities as they become due. Liquidity ratios show the cash level of the company \& shows the ability to convert other assets into cash to pay off liabilities \& other obligations. Liquidity ratios not only show how much cash the company has but also show how easy it will be for a company to raise cash or convert assets into cash. Here are some common liquidity ratios:

Current Ratio:

Current ratio is a liquidity ratio that measures a company's ability to pay off its short term liabilities with its current assets. This ratio is very important because the short term liabilities will become due in the next year. This means a company has limited time to raise fund to pay off these liabilities. So, the companies that have larger amount of current assets will more easily be able to pay off the current liabilities when they become due.

Formula

$$
\text { Current Ratio }=\frac{\text { CurrentAssets }}{\text { CurrentLiabilities }}
$$

Analysis for Lanka Bangla Finance Ltd:

The current ratio helps the investors \& creditors to understand the liquidity position of a company \& how well the will be able to pay off its current liabilities. The ratio explains the company's current debts in terms of current assets. A higher current ratio is always expected than a lower current ratio as the ratio shows the ability to pay off current debts with current assets. If a company has to sell its fixed assets, it means the company has not enough current assets to support the current liabilities. It means the company is losing money. It also means the company is not generating enough profit from support activities. It may cause from poor collection procedure. This ratio focuses on the overall debt burden of the company. If a company has higher current debt, then it will mean that the company will suffer with cash.

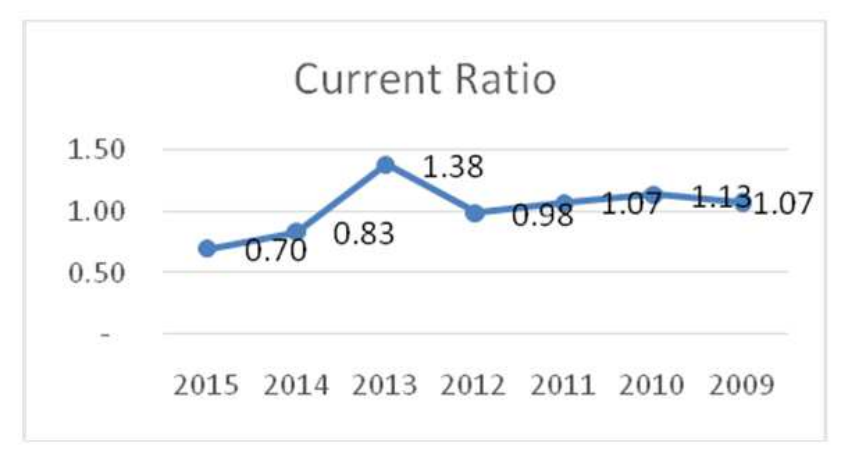

Source: Annual report of Lanka Bangla Finance Ltd (LBFL)

Figure 1. Current Ratio.

As we can see from the Chart $\&$ the graph that current ratio of LBFL was higher till 2013. After that the ratio went down. It indicates LBFL managed it's current debts better with it's current liabilities before 2014. It also indicates that the company is losing money as its current assets are decreasing. It also means that the company might be in a problem in collecting it's receivables.

Time interest earned ratio

The time interest earned ratio measures the proportionate amount of income that can be used to cover the interest expense in the future.

From some points the time interest earned ratio is considered as the solvency ratio because it measure the ability to pay off the debt service payments. As with most expenses if the company cannot pay off these expenses, the company will go bankrupt \& cease to exist.

\section{Formula}

$$
\text { Time Interest Earned Ratio }=\frac{\text { earningbeforeInterst\&taxes }}{\text { InterestExpense }}
$$

Analysis for Lanka Bangla Ltd:

The time interest earned ratio is showed in numbers rather than percentage. The ratio indicates how many times the company will be able to pay off its interest with its income before tax. This means a larger ratio is considered to be more favorable than the smaller ratio. If a company has time interest earned ratio of 4 , it means the company has the ability to pay off the interest 4 times over. In other words, the company's income is 4 times higher than its interest expenses. Here higher ratios are less risky \& lower ratio shows credit risk. 


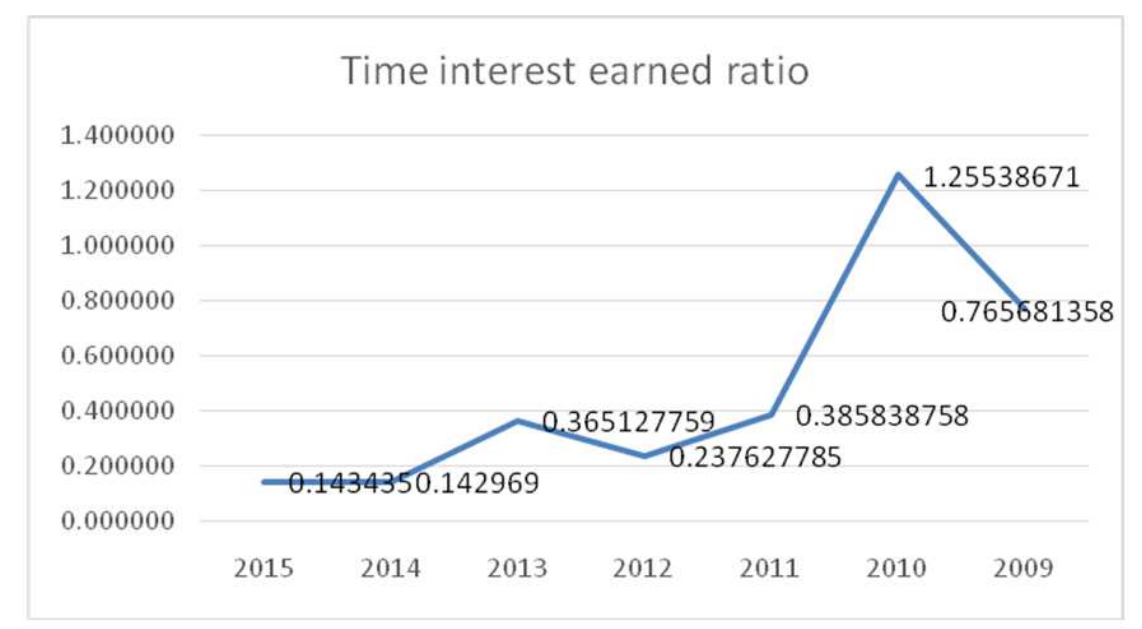

Source: Annual report of Lanka Bangla Finance Ltd (LBFL)

Figure 2. Times interest earned ratio.

As we can see here, the ratio is much lower from 2011 to 2015. It was at the pick in 2010. After that it went in a much lower position. It clearly indicates that LBFL is in a situation of credit risk in recent years. LBFL is facing problem in paying its interest expenses with its earnings. It can also be assumed that LBFL was in problem in paying interest expenses in last seven years.

\subsection{Solvency Ratio or Financial Leverage Ratio}

Solvency ratios or the financial leverage ratio showsa company's ability to sustain operations by comparing the debt levels with equity assets \& earnings. In other word the solvency ratios indentify how well the company is able to pay of its expenses in the long term. Solvency ratio is mainly focused on long term liabilities than the payment of short term or current liabilities.

The most common solvency ratios are:

Debt to Equity Ratio

The debt to equity ratio is the ratio that compares the company's total debt to it's total equity. This ratio shows a percentage that how much financing for the company comes from the creditors \& investors. A higher ratio show the higher creditor's investment is used than the investors financing.

Formula

Debt to Equity ratio $=\frac{\text { TotalLiabilities }}{\text { TotalEquity }}$

Analysis for LBFL:

Different industries have different debt to equity benchmarks. A debt ratio 0.5 means the company has half libilities as it is in equity. A debt to equity ratio of 1 means, investors \& creditors have equal stake in the business. A lower debt to equity ratio is always expected as it shows a much stable financial position. Companies with higher debt to equity ratio are considered to be more risky to the investors \& creditors. A higher debt to equity ratio is risky to creditors because they think that investors are not contributing to the company as the creditors do. It implies that that the investors are not investing in the business because the company is not performing well.

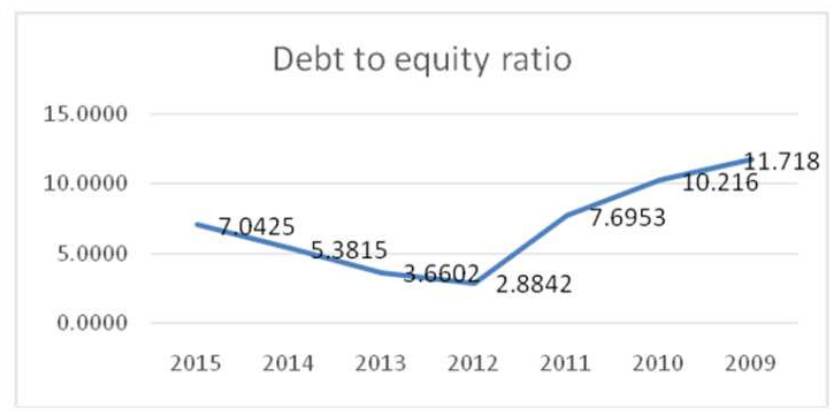

Source: Annual report of Lanka Bangla Finance Ltd (LBFL)

Figure 3. Debt to equity ratio.

A lower Debt Ratio is always expected as it shows a better financial stability. But in case of LBFL, the situation was not so favorable. In last seven years the debt ratio was well over 1. The lowest was in 2012 at 2.88. In 2009 it was highest at 11.718. In 2015, the Ratio is 7.04. LBFL always had a problem in paying the liabilities with the equity.

Equity Ratio:

Equity ratio is the solvency ratio which measures the amount of assets that is financed by owner's investments. This ratio is calculated by comparing total equity to company's total assets. Firstly the equity ratio expresses how much of the company's total assets is owned by the owners. This means after paying off all the liabilities, how much the investor will end up? Secondly this ratio also measures, how much of the company's assets is financed by debt. This means, by equity ratio we will find out how much of the company's assets is financed by owners. The inverse of this ratio is the percentage that points out how much is invested by debt. This means how much leveraged is the company. 
Formula

$$
\text { Equity Ratio }=\frac{\text { TotalEquity }}{\text { TotalAssets }}
$$

Analysis for LBFL:

A higher equity ratio is always favourable for the company. Higher equity ratio shows to the potential investors that, the company is sustainable enough \& less risky to the future loans. As equity financing is much cheaper than debt financing because of the interest obligations related to debt. More equity financing is expected by the investors.

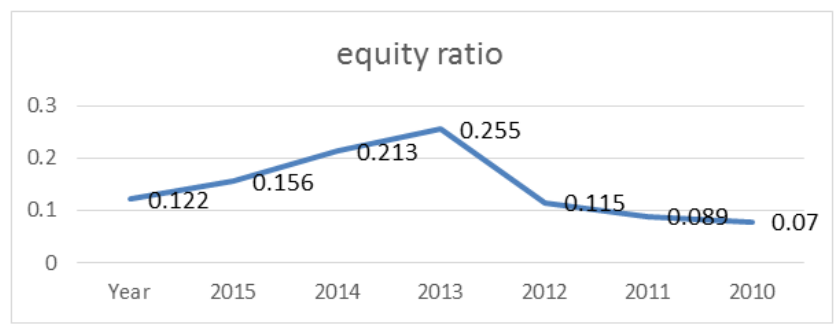

Source: Annual report of Lanka Bangla Finance Ltd (LBFL)

Figure 4. Equity ratio.

The equity ratio indicates the sustainability of the company. It attracts investors to invest more in the business. As we can see in the chart \& the graph that the ratio was in an increase till 2011 but after that it started declining. It means that the company has received higher debt financing in last 3 years.

Debt ratio

Debt ratio is the ratio that calculates the total liabilities of a company compared to its total assets. In other word, it can also be said that, this ratio shows how many asset $\mathrm{s}$ must be sold to pay off all the liabilities of the company. This ratio helps investors to analyze the overall debt burden of the company \& the firm's ability to pay off all of its liabilities.

Formula

$$
\text { Debt Ratio }=\frac{\text { TotalLiabilities }}{\text { TotalAssets }}
$$

\section{Analysis for LBFL:}

The debt ratio calculates the total liabilities as the percentage of total assets. Because of that, a lower debt ratio is always favorable. A lower debt ratio means that the company has a more stable business with a sound potential longevity because the company has lower amount of debt compared to its total assets. A debt ratio of 0.5 means the company has liabilities which are only $50 \%$ of its total assets. A debt ratio of 1 means the company have to sell all of its assets to pay off all of its liabilities. But once all of the assets are sold the business will no longer run. The debt ratio is so important because, creditors are always concerned of getting repaid. But when there will be a higher debt ratio, the company will be under a higher debt burden. Then the creditors will no longer provide the company fund. Companies must look for equity financing rather than debt financing.

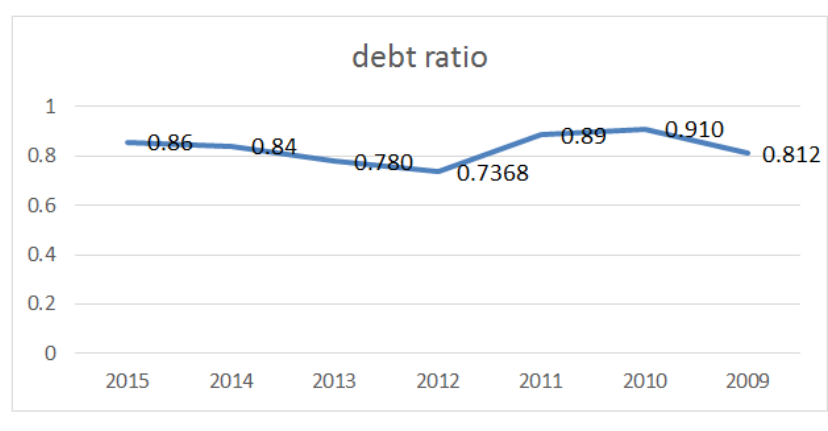

Source: Annual report of Lanka Bangla Finance Ltd (LBFL)

Figure 5. Debt ratio.

The debt ratio shows the percentage of liability of total asset. From the chart $\&$ graph we can see that in last seven years the ratio was below $1 \&$ in a stable position. It indicates that the company has maintained a liability position in a reasonable manner, but it also states that the ratio is in increasing mode since 2013 which means that the company has higher liabilities.

\section{Profitability Ratios}

Profitability ratios compare income statements to find out whether a company has the ability to generate profit from its operation. This ratio mainly shows how well a company can generate profit from its operations. Investors normally use profitability ratios to judge the company's return on investment. These profitability ratios also show how well the company is using the assets. Here are some key profitability ratios:

\section{Profit Margin Ratio:}

Profit margin ratio is that profitability ratio that measures the amount of net income earned with each dollar sales generated. This ratio is calculated from comparing the net income \& net sales of the company. In other words, profit margin ratio shows how much sales are left after all the expenses are paid off. Creditors use this ratio to find out how effectively the company is converting its sales into profit. Investor will make sure high amount of profit generated that will be enough to cover all the expenses. They will make sure the sales are well enough to pay off all the loans. In other words, it can be said that, this ratio shows whether the company is running efficiently or not.

Formula

$$
\text { Profit Margin }=\frac{\text { NetIncome }}{\text { Netsales }}
$$

Analysis for LBFL:

The profit margin ratio indicates what percentage of income is generated from a certain level of sales. This ratio also measures that how well the company is managing its debts \& liabilities to its net sales. Companies can do that by two ways. One, they can increase sales \& keep the expenses constant or they can keep the sales constant \& decrease the expenses. As in this ratio the net income is compared to net sales, then a higher profit margin is always expected. 


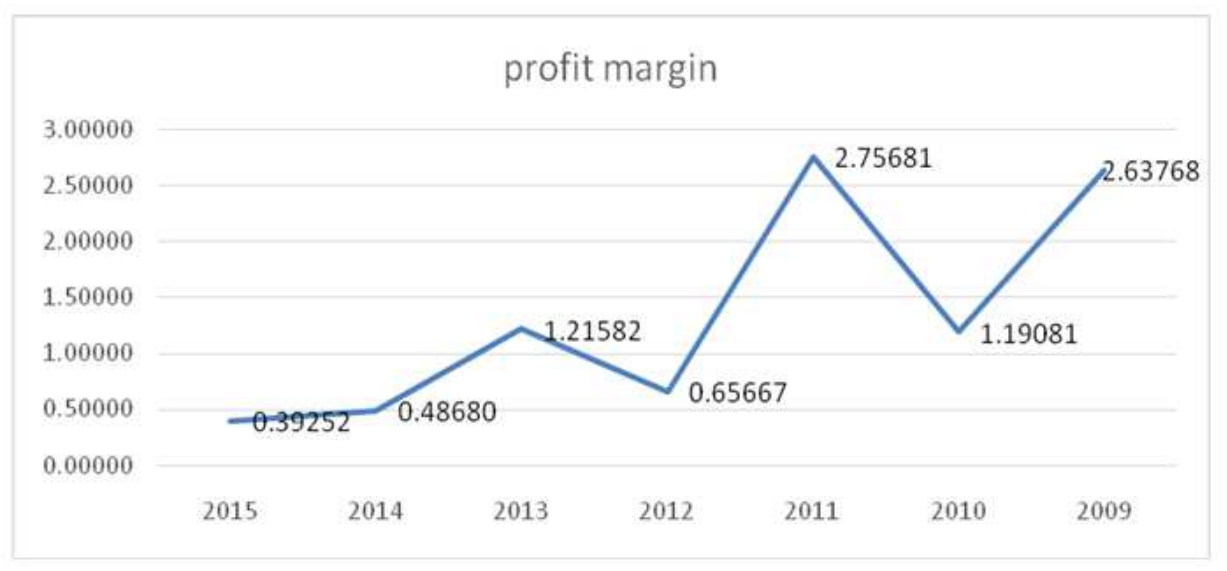

Source: Annual report of Lanka Bangla Finance Ltd (LBFL)

Figure 6. Profit Margin ratio.

Profit margin shows how much profit is generated from a certain amount of sales. The profit margin ratio directly measures what percentage of sales is made up of net income. A higher profit margin is always expected. But in case of LBFL, the ratio is in declining mode since 2013. Earlier, the company had a bumpy graph of profit margin. The graph also indicates that LBFL always had problem in keeping up its profit margin.

Return on asset or ROA

The return on asset or ROA is the ratio which measures the percentage of net income is produced by using the total asset of a company in a period. This is calculated by comparing the net income to the total assets. In other words, the return on asset shows how efficiently the company is managing its assets to generate income in a certain period. This ratio helps both creditors \& the investors. They will see how well the company is converting its investments in assets into profits.
In a word, this ratio shows how profitable the company's assets are.

Formula

$$
\mathrm{ROA}=\frac{\text { NetIncome }}{\text { AverageTotalAsset }}
$$

Analysis for $L B F L$ :

The return on asset measures how well the company is producing income by employing its assets. This ratio also shows how well the company can convert the money used to purchase the assets into net income or profit. A higher ROA is desired as it shows the company in effectively managing its assets to produce greater amount of net income. A higher ROA indicated an upward trend in the business. This ratio is more useful to measure between different companies in the same industry. It can measure the different use of assets in different companies.

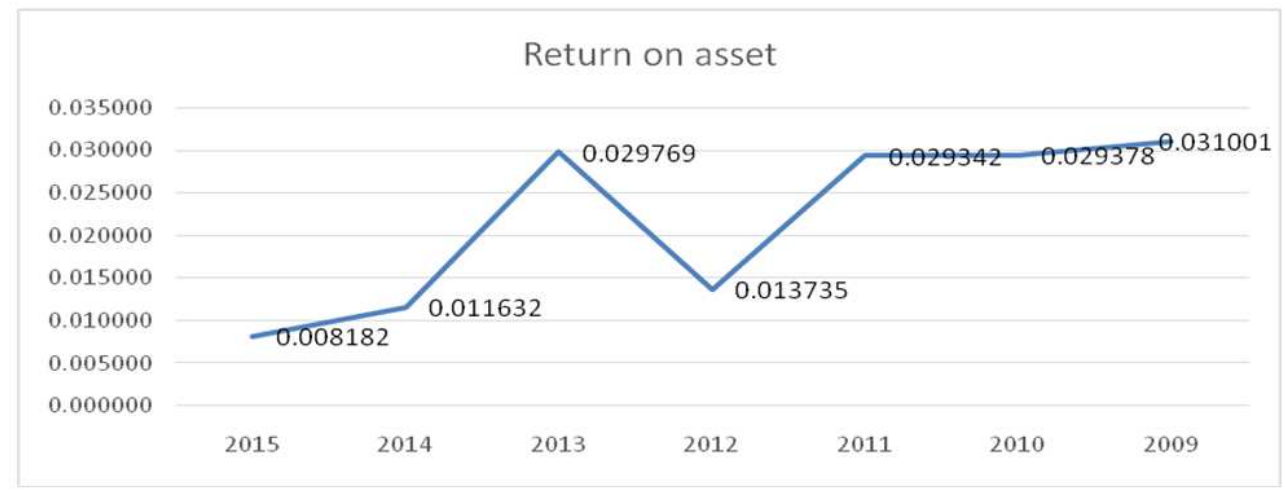

Source: Annual report of Lanka Bangla Finance Ltd (LBFL)

Figure 7. ROA (Return of Assets).

The return on assets ratio measures how effectively a company can earn a return on its investment in assets. That means how much profit is generated from a certain amount of invested assets. So a higher ROA is always expected. But in case of LBFL, the ratio was always much lower than 1 . That means the assets of LBFL are not generating enough profit for the company. But the ratio declined more from 2014. This means the company is not properly managing the assets to effectively produce profit.

Return on Equity or ROE

Return on equity is the ratio that shows the ability of a company to produce profits from the investment of the 
shareholders of the company. In other words, this ratio shows how much income is generated from each dollar invested or each dollar of common shareholder's equity. This ratio is important to the shareholders because they want to see how efficiently the company is using their money. ROE is important for analyzing the growth of the company.

Formula

$$
\mathrm{ROE}=\frac{\text { NetIncome }}{\text { shareholder'sEquity }}
$$

Analysis for LBFL:

ROE shows how much profit is generated from the invested money of the shareholders. This is a profitability ratio for the investors. This ratio measures how much money is produced from only using the shareholder's equity. For this reason, a higher ROE is always expected. This is so, because investors want to see that the company is using their money efficiently. But this ratio cannot be used to compare different companies.

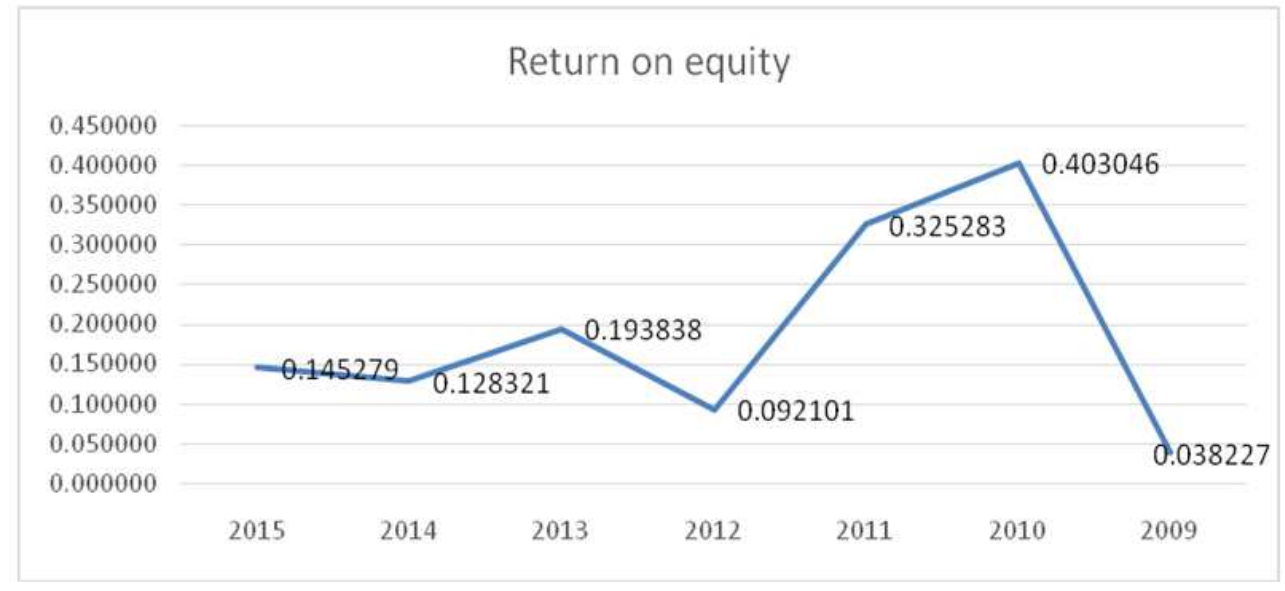

Source: Annual report of Lanka Bangla Finance Ltd (LBFL)

Figure 8. ROE (Return of Equity).

The return on equity ratio or ROE is a profitability ratio that measures the ability of a firm to generate profits from its shareholders investments in the company. The investors want to see a higher ratio because this indicates that the company is using its investors' funds effectively. As we can see here, the ration is in declining mode since 2012. It means that the company is not using its investors fund to generate profit. It also indicates that the trend of earning is not satisfactory.

\section{Return on Capital Employed}

Return on capital employed is the ratio that measures how efficiently a company is generating profit from its total employed capital. This ratio is calculated by comparing the net operating profit to the capital employed. In other words ROCE shows how much dollars are generated as profits after employing 1 dollar. ROCE is a long term profitability ratio which ensures how effectively assets are used to generate profit considering the long term financing.

Formula

$$
\text { ROCE }=\frac{\text { netoperating Profit }}{\text { TotalAssets-TotalLiabilities }}
$$

Analysis for LBFL:

ROCE shows how much profit is generated from employing each dollar in the business. Higher ROCE is always favorable to investors. For instance if ROCE is 0.2 , it states if investor employed 1 dollar in the business, it has generated 20 cents of profit. Investors are interested in this ROCE to see how efficiently the company is using its capital employed as well as long term financial strategies. a company that has a small dollar amount of assets but a large amount of profits will have a higher return than a company with twice as many assets and the same profits.

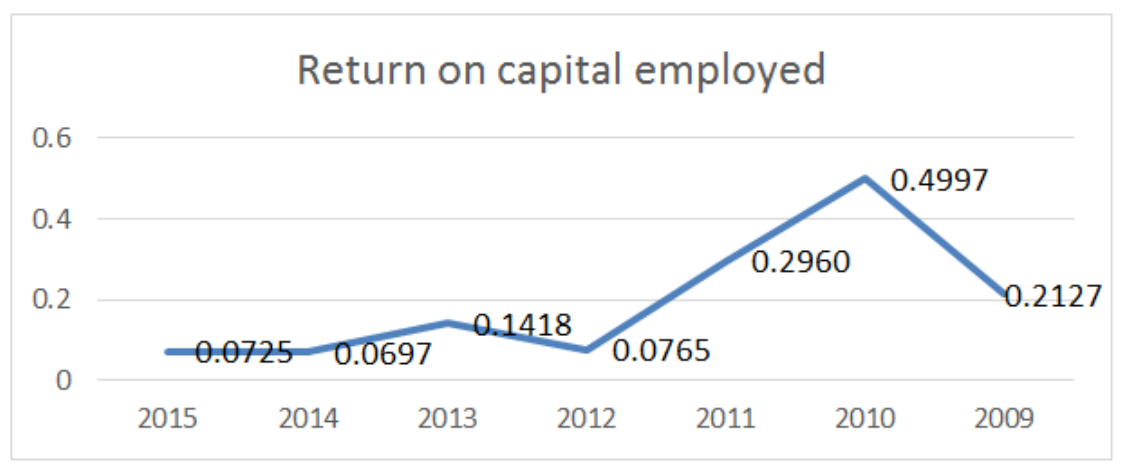

Source: Annual report of Lanka Bangla Finance Ltd (LBFL)

Figure 9. ROCE (Return on Capital Invested). 
The return on capital employed ratio shows how much profit of employed capital generates. A higher ratio is expected in this case. Investors are interested in the ratio to see how efficiently a company uses its capital employed as well as its long-term financing strategies. In case of LBFL, the ratio shows a less favorable scenario. It shows from 2012 the ratio is declining which means LBFL is not employing the capital effectively to produce profit. In last two years the ratio showed an earning less than a paisa.

Asset Turnover Ratio

Asset Turnover Ratio is the ratio which measures the company's ability to generate interest revenue from its assets. In other words, asset turnover ratio ensures how efficiently the company is using its assets to produce revenue. It can also be said that this ratio states how much BDT of revenue is generated from using $1 \mathrm{BDT}$ of asset. That is why this ratio is shown in percentage.

Formula

$$
\text { Asset Turnover Ratio }=\frac{\text { NetInterestRevenue }}{\text { TotalAssets }}
$$

Analysis for $L B F L$ :

As we know that this ratio measures how efficiently a firm uses its assets to generate revenue, so a higher ratio is always more favorable. Higher turnover ratios mean the company is using its assets more efficiently. Lower ratios mean that the company isn't using its assets efficiently and most likely have management or production problems. For LBFL, it can be seen that the ratio is in a declining mode from 2013. That means the company is not effectively generating profit from its assets. It can also be assumed that the company is facing problem in managing its assets.

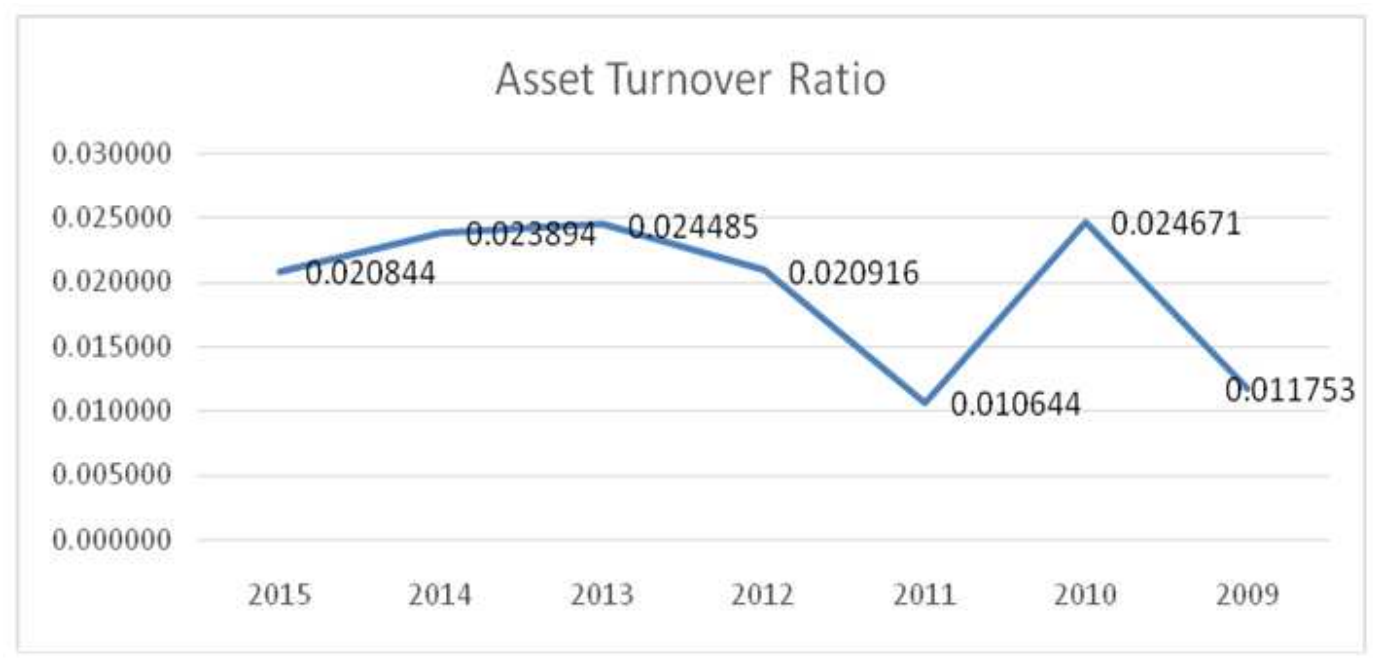

Source: Annual report of Lanka Bangla Finance Ltd (LBFL)

Figure 10. Asset Turnover Ratio.

\section{Market Prospect Ratios}

Market prospect ratio IS used to compare the stock price with other financial component as earnings \& dividend payments of the publicly traded companies. Investors use market prospect ratio to analyze the stock price trend \& dividend payment trend \& per share earnings trend of the company. In other words, market prospect ratio shows how much amount is expected to be earned after their investment. These ratios are helpful for investors to predict how changes in stock prices will be based on current earnings and dividend measurements.

Here are some of the important market prospect ratios:

Earnings per share or EPS

Earnings per share are also known as the net income per share. It is the market prospect ratio that measures how much income is earned per share. In other words, this is the amount of money each share of stock would receive if all of the profits were distributed to the outstanding shares at the end of the year.

Earnings per share also show how profitable the company is on the basis of share portion. So by this ratio more companies can be compared in same industry.

Formula

$$
\mathrm{EPS}=\frac{\text { NetIncome }- \text { PrefferedDividends }}{\text { WeightedAverageCommonSharesOutstanding }}
$$

\section{Analysis for LBFL:}

Earnings per share ratio show the income that is generated from every share. For this reason a higher EPS is always favorable for the investor. Higher EPS means they have more profit to be distributed among the shareholders than the lower EPS. 


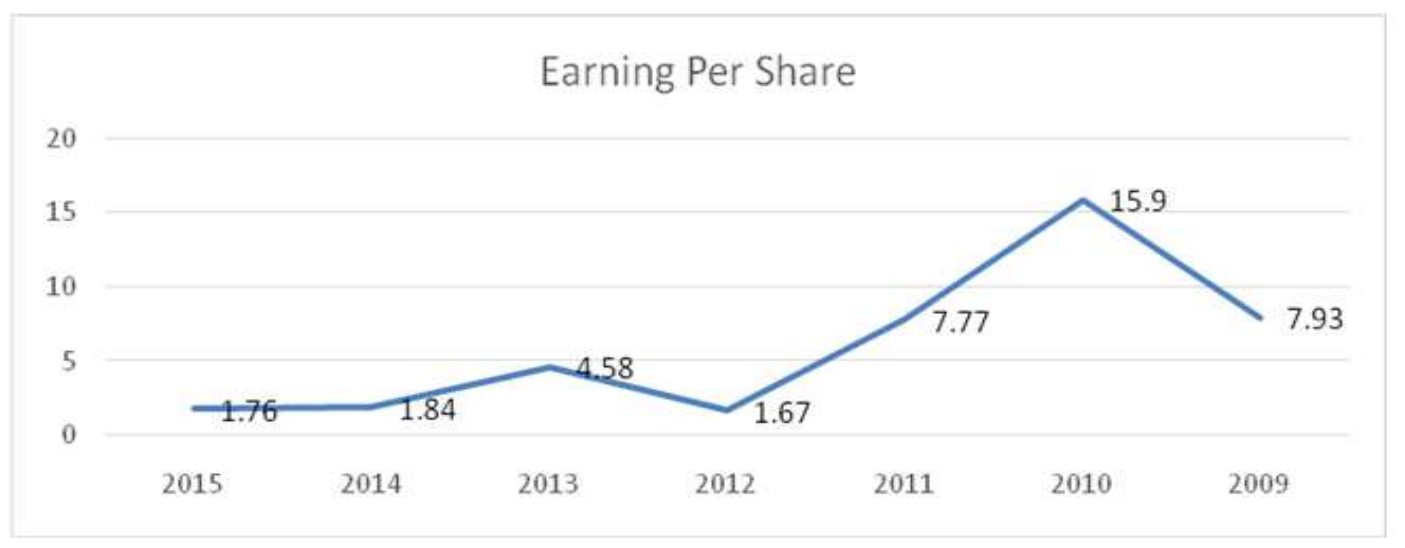

Source: Annual report of Lanka Bangla Finance Ltd (LBFL)

Figure 11. EPS (Earnings per Share).

A higher EPS is always expected because it shows the profitability of the firm. But in case of LBFL the EPS is decreasing since 2014. In last two years EPS was just less than $2 \&$ it is declining. It indicates that the profit generating capacity of LBFL is getting weaker as number of shares has increased but the net income is not increased in that proportion. This caused a lower EPS than previous years.

Price Earnings Ratio or P/E ratio

The price earnings ratio or $\mathrm{P} / \mathrm{E}$ ratio is the market prospect ratio that measures the market value of the stock relative to its earning by comparing the market price per share to the earning per share. In other words, this ratio shows how much investor is willing to pay for this stock in this earning.

Investors use this $\mathrm{P} / \mathrm{E}$ ratio to analyze what should be the market price for a stock by predicting the future EPS. Investors also ensure how much the fair market price of the stock should be at a certain earning per share. Investors use this ratio to decide what multiple of earnings a share is worth. In other words, how many times earnings they are willing to pay.

Formula

$$
\mathrm{P} / \text { E Ratio }=\frac{\text { marketValuePricePerShare }}{\text { EarningPerShare }}
$$

Analysis for LBFL:

Apriceearning ratio indicates the expected market price of a share based on the earnings. A higher $\mathrm{P} / \mathrm{E}$ ratio is always expected because it represents a positive future performance $\&$ investors are willing to pay more for the company. A company with a lower ratio, on the other hand, is usually an indication of poor current and future performance. This could prove to be a poor investment.

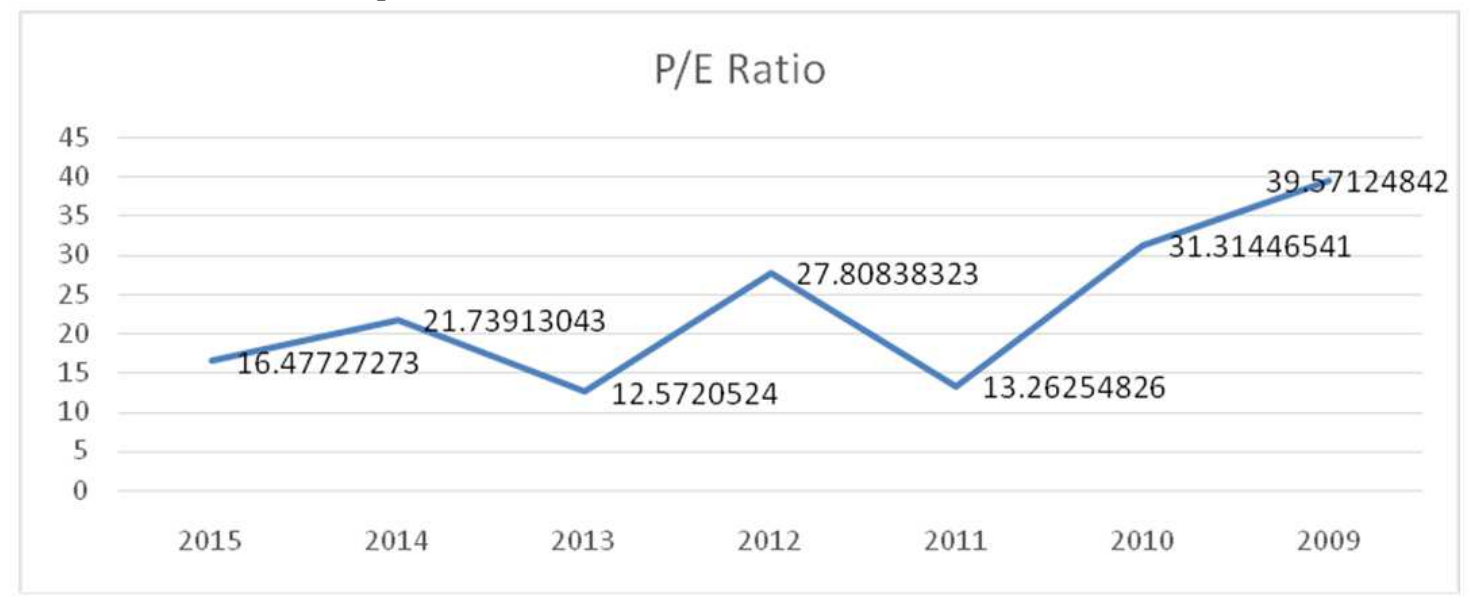

Source: Annual report of Lanka Bangla Finance Ltd (LBFL)

Figure 12. P/E (Price-Earning) Ratio.

The price to earnings ratio indicates the expected price of a share based on its earnings. As a company's earnings per share being to rise, so does their market value per share. A company with a high $\mathrm{P} / \mathrm{E}$ ratio usually indicated positive future performance and investors are willing to pay more for this company's shares. In case of LBFL, the ratio shows a bumpy mode in the graph. But in last two years the ratio is declining. It means LBFL is struggling to maintain a better market price of the share of LBFL.

Dividend payout Ratio

The dividend payout ratio is measured to calculate how much of the company's earnings are distributed among the shareholders in the form of dividend. This ratio also shows how much portion of income is kept for company operation 
$\&$ how much portion is kept for the investors. Investors are really interested in this ratio because, they want to know whether the company is paying out a reasonable portion of the income to them or not. Conversely, some companies want to spur investors' interest so much that they are willing to pay out unreasonably high dividend percentages.

Formula

$$
\text { Dividend Payout Ratio }=\frac{\text { TotalDividends }}{\text { NetIncome }}
$$

Analysis for LBFL:
Since investors want to see a steady stream of dividend that is paid out to them than ups \& downs in the payment, a consistent trend in the dividend payment is always expected than a higher or lower dividend payment.

Conversely, a company that has a downward trend of payouts is alarming to investors. For example, if a company's ratio has fallen a percentage each year for the last five years might indicate that the company can no longer afford to pay such high dividends. This could be an indication of poor operating performance.

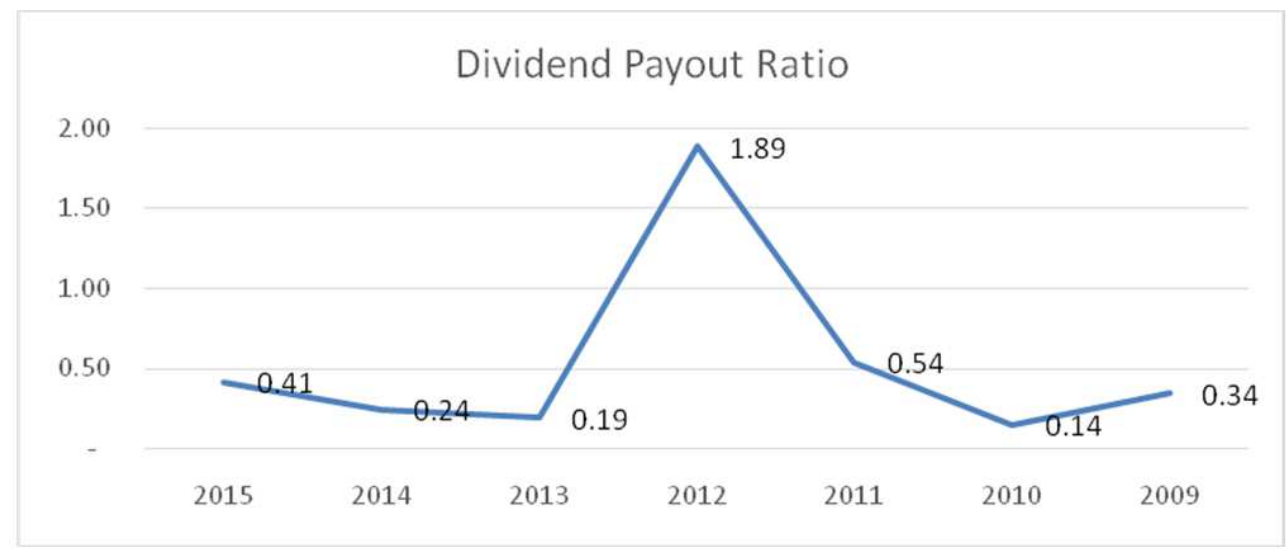

Source: Annual report of Lanka Bangla Finance Ltd (LBFL)

Figure 13. DPR (Dividend Payout Ratio).

Since investors want to see a steady stream of sustainable dividends from a company, the dividend payout ratio analysis is important. A consistent trend in this ratio is usually more important than a high or low ratio. In case of LBFL, as we can see from the chart \& graph that from 2013 the dividend payout ratio is increasing \& it shows a consistent mode. Before that the ratio was at pick of 1.89 in 2012. This shows a better indication in dividend payment in recent years.

\section{Dividend Yield Ratio}

Dividend yield ratio is the measurement that indicates the amount of cash dividend that is distributed among the shareholders relative to its market value per share. Investors invest their money to earn a reasonable profit from the investment in terms of stock dividend or cash dividend. Some companies choose to pay dividends on a regular basis to spur investors' interest. These shares are often called income stocks. Other companies choose not to issue dividends and instead reinvest this money in the business. These shares are often called growth stocks.

Formula

$$
\text { Dividend Yield }=\frac{\text { cashDividendPerShare }}{\text { MarketValuePerShare }}
$$

Analysis for LBFL:

Investors use dividend yield to calculate the cash flow they will get from their investment in the stocks. Investors want to know that how much dividend they are getting for every dollar that the stock is worth. This is better to have a higher dividend yield comparing to the lower yields.

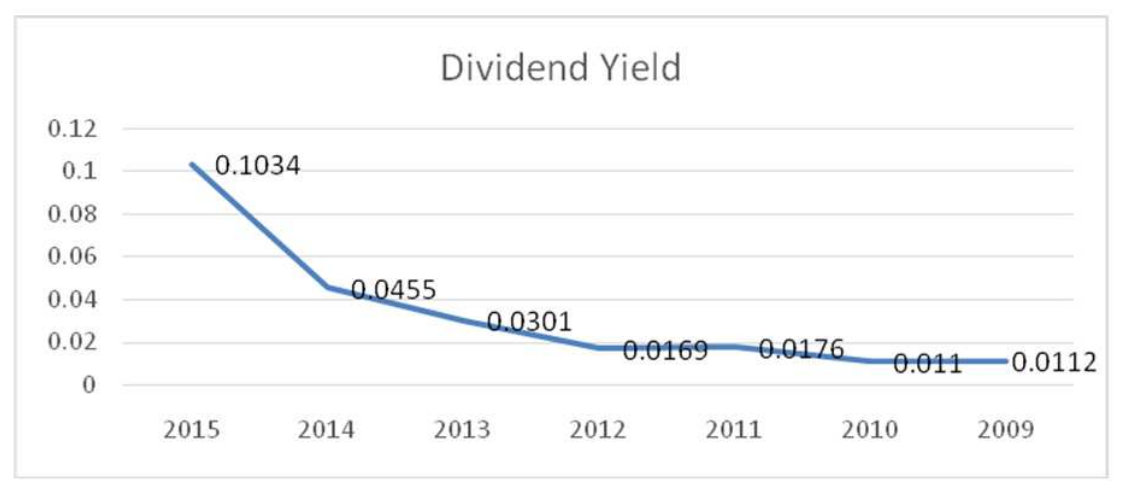

Source: Annual report of Lanka Bangla Finance Ltd (LBFL)

Figure 14. Dividend Yield. 
As the dividend yield ratio indicates how much dividend the investors are getting from their invested stock, a higher ratio is always expected. But it is seen from both the graph \& the chart that the ratio is increasing every year from 2009. But from 2012, the rate of increase has got a tremendous pace. Since then the dividend yield is always increasing. It means LBFL is more likely to provide cash dividend each year.

\section{Equity Multiplier}

The equity multiplier is the ratio that measures, how much of company's total assets are financed by the shareholders of the company. This is calculated by comparing the total assets with the total shareholder's equity. In other words, the equity multiplier shows the percentage of assets that are owned by the shareholders.

Formula

$$
\text { Equity Multiplier }=\frac{\text { TotalAssets }}{\text { TotalShareholder'sEquity }}
$$

Analysis for LBFL:

A higher ratio of equity multiplier means, more assets were funded by debt than equity. In other words, in a company investors invested less assets than the creditor. A lower ratio always shows a conservative \& favourable situation than the higher one. A lower ratio means the company is less dependent on debt financing than equity.

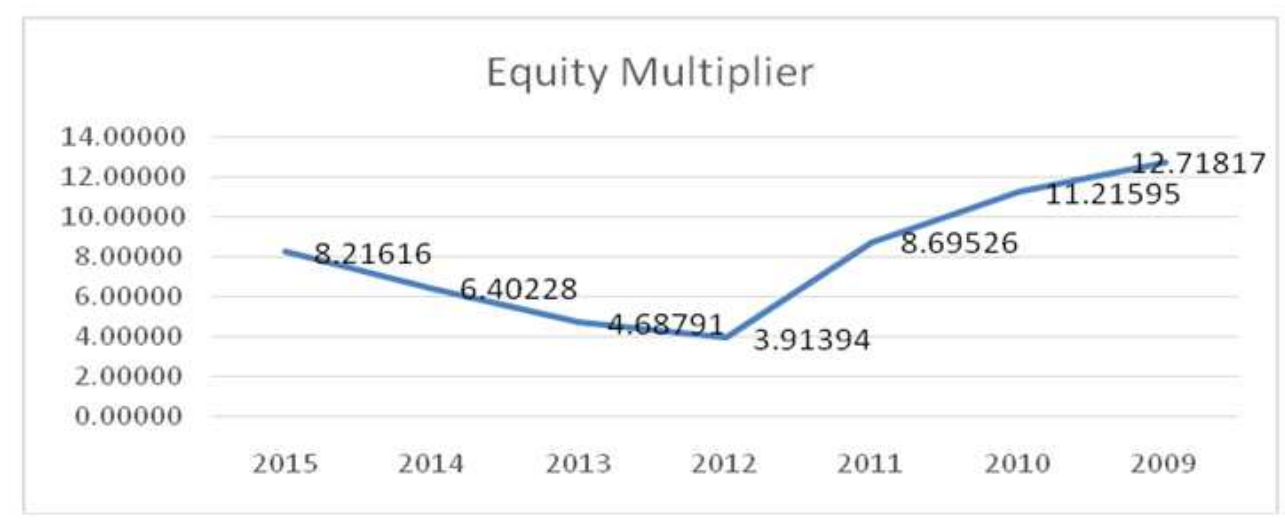

Source: Annual report of Lanka Bangla Finance Ltd (LBFL)

Figure 15. Funds Management Ratio (Equity Multiplier).

The equity multiplier is a ratio used to analyse a company's debt and equity financing strategy. A higher ratio means that more assets were funding by debt than by equity. Lower multiplier ratios are always considered more conservative and more favourable than higher ratios because companies with lower ratios are less dependent on debt financing and don't have high debt servicing costs. In case of LBFL, from the chart \& graph it shows that the ratio is increasing from 2013 which indicated the company is getting dependent on the debt financing rather than equity. This put the company in a more risky position.

Du Pont Analysis

The Dupont analysis also called the Dupont model is a financial ratio based on the return onequity ratio that is used to analyze a company's ability to increase its return on equity. In other words, this model breaks down the return on equity ratio to explain how companies can increase their return for investors.

The Dupont analysis looks at three main components of the ROE ratio as revealed below:

\section{Profit Margin}

Total Asset Turnover

Financial Leverage

Based on these three performances measures the model concludes that a company can raise its ROE by maintaining a high profit margin, increasing asset turnover, or leveraging assets more effectively. The Dupont Corporation developed this analysis in the 1920s. The name has stuck with it ever since.

\section{Formula}

ROE $=$ Profit Margin $x$ Total Asset Turnover X Financial Leverage

\section{Analysis for $L B F L$ :}

This model was developed to analyze ROE and the effects different business performance measures have on this ratio. So investors are not looking for large or small output numbers from this model. Instead, they are looking to analyze what is causing the current ROE. For instance, if investors are unsatisfied with a low ROE, the management can use this formula to pinpoint the problem area whether it is a lower profit margin, asset turnover, or poor financial leveraging. Once the problem area is found, management can attempt to correct it or address it with shareholders. Some normal operations lower ROE naturally and are not a reason for investors to be alarmed. For instance, accelerated depreciation artificially lowers ROE in the beginning periods. This paper entry can be pointed out with the Dupont analysis and shouldn't sway an investor's opinion of the company.

$\mathrm{ROE}=$ Profit Margin $\mathrm{x}$ Total Asset Turnover X Financial Leverage 


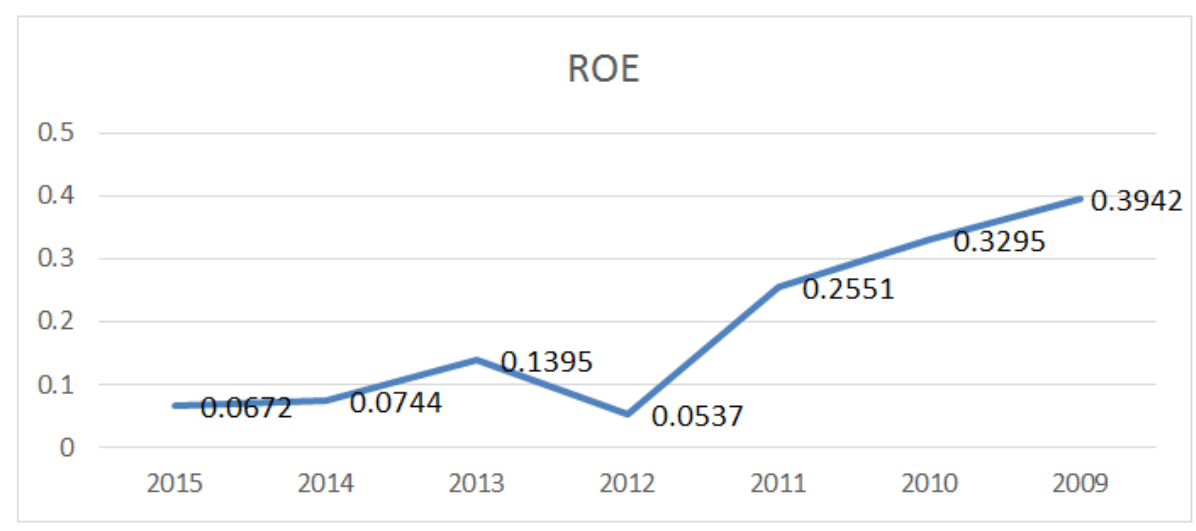

Source: Annual report of Lanka Bangla Finance Ltd (LBFL)

Figure 16. Components of $R O E$.

This model was developed to analyze ROE and the effects different business performance measures have on this ratio. So investors are not looking for large or small output numbers from this model. Instead, they are looking to analyze what is causing the current ROE. So, in this analysis from the chart \& graph of LBFL, we can see that, ROE is in declining mode from 2014. As we can see, in 2014, there was a drastic fall of profit margin that caused ROE to decline. In 2015, profit margin has gone further lower. Although financial leverage was higher but a lower profit margin that caused the ROE to decline. In 2013, profit margin was higher but the financial leverage was lower, but the growth of profit margin was high so ROE increased in 2013. We can also see that in the previous years the ROE was in the same trend. Profit margin was the factor that affected the ROE to fluctuate.

\section{Findings}

In our study I have tried give readers a proper \& detail view of the current position of Lanka Bangla Finance limited. The several important finding are stated below:

(a) Current ratio of LBFL was higher till 2013. After that the ratio went down. It indicates $\mathrm{LBFL}$ managed its current debts better with its current liabilities before 2014. It also indicates that the company is losing money as its current assets are decreasing. It also means that the company might be in a problem in collecting its receivables.

(b) Time Interest earned ratio is much lower from 2011 to 2015. It was at the pick in 2010. After that it went in a much lower position. It clearly indicates that LBFL is in a situation of credit risk in recent years. LBFL is facing problem in paying its interest expenses with its earnings. It can also be assumed that LBFL was in problem in paying interest expenses in last seven years.

(c) In last seven years the debt ratio was well over 1 . The lowest was in 2012 at 2.88. In 2009 it was highest at 11.718. In 2015, the Ratio is 7.04. LBFL always had a problem in paying the liabilities with the equity.

(d) The equity ratio was in an increase till 2011 but after that it started declining. It means that the company has received higher debt financing in last 3 years.

(e) In last seven years the debt ratio was below $1 \&$ in a stable position. It indicates that the company has maintained a liability position in a reasonable manner. But it also states that the ratio is in increasing mode since 2013 which means that the company has higher liabilities.

(f) The profit margin of LBFL was better in most of the time. Nut since 2013, the profit margin has become below 1. Now Lanka Bangla Finance is maintaining a declining profit margin.

(g) Return on Asset of LBFL was always much lower than 1. That means the assets of LBFL are not generating enough profit for the company. But the ratio declined more from 2014. This means the company is not properly managing the assets to effectively produce profit.

(h) Return on Equity of LBFL is in declining mode since 2012. It means that the company is not using its investors fund to generate profit. It also indicates that the trend of earning is not satisfactory.

(i) Asset Turnover ratio is in a declining mode from 2013. That means the company is not effectively generating profit from its assets. It can also be assumed that the company is facing problem in managing its assets.

(j) From 2012 the Return on Capital employed is declining which means LBFL is not employing the capital effectively to produce profit. In last two years the ratio showed an earning less than a paisa.

(k) EPS is decreasing since 2014. In last two years EPS was just less than $2 \&$ it is declining. It indicates that the profit generating capacity of LBFL is getting weaker as number of shares has increased but the net income is not increased in that proportion. This caused a lower EPS than previous years.

(1) In last two years the $\mathrm{P} / \mathrm{E}$ ratio is declining. It means LBFL is struggling to maintain a better market price of 
the share of LBFL.

(m) From 2013 the dividend payout ratio is increasing \& it shows a consistent mode. Before that the ratio was at pick of 1.89 in 2012. This shows a better indication in dividend payment in recent years.

(n) Equity Multiplier is increasing from 2013 which indicated the company is getting dependent on the debt financing rather than equity. This put the company in a more risky position.

\section{Recommendations \& Conclusions}

From the abovementioned findings we can provide several recommendations for the company to make a better position in the market. LBFL must be careful in collecting the receivables. If they were able to increase receivables they will be able to cover up the liabilities with these. LBFL must also work on paying off interest expenses. Due to interest expenses the net income is hampered because higher interest expense subsides the net income of the company. From the debt to equity ratio, debt ratio \& equity ratio, it is seen that all these ratios are in a decreasing mode. This means that the company is working with higher amount of liability \& they have lower equity investment. LBFL must increase the equity financing to debt financing. They must also try to lower the liabilities. The profit margin is decreasing due to higher liabilities. So, LBFL must decrease liabilities \& move on to higher equity investment which will ultimately lower the liabilities or the debts \& increase the net income \& profit. From the report it is clear that LBFL is not using it assets to generate income or it can be said that assets are not generating enough income. LBFL must use assets in more effective way to generate more income. EPS \& P/E ratio is in a decreasing mode $\&$ at the same time the dividend payout ratio is in increasing mode. This means the company is paying out dividend more. But the company must make a balance between them. Overall we can say that the company is suffering from using its assets \& collecting the receivables. But they are trying to get a healthy income at the end of each year. But LBFL is still needs to work more aggressively to capture the market.

\section{References}

[1] Anolli, m. (2013). Retail credit Risk Management. Hampshire: macmillan Publishers Limited.

[2] Brigham, E. F., \& Houston, J. F. (2011). Fundamentals of Financial Management. (10th Ed.). Ohio, USA: Thomson South Western.

[3] Elizabeth, D. \& Greg, E. (2004). Efficiency, customer service and financial performance among Australian financial Institutions. International Journal of bank marketing, 22(5), 319-342.

[4] Investor Relation: lanka Bangla Finance. (n.d.). Retrieved from LankaBangla Finance: https://www.lankabangla.com/investor-relations/

[5] Iqbal, M. j. (2012). Banking sector's performance in Bangladesh- An application of selected CAMELS ratio. A project submitted in partial fulfillment of the requirements for the degree of Professional Master in Banking and Finance, Asian Institute of Technology, Thailand.

[6] Kumbirai, M. \& Webb, R. (2010). A financial ratio analysis of commercial performance in South Africa. African Review of Economics and Finance, 2(1), 30-53.

[7] Payne, R (2011). Finance's Role in the Organization. Institute of Chartered Accountants in England and Wales, ISBN 978-184152-855-7.

[8] S. Rose, P. (2013-2014). Commercial Bank Mangement. McGraw-Hill.

[9] Siddiqui, M. A., \& Shoaib, A. (2011). Measuring performance through capital structure: Evidence from banking sector of Pakistan. African Journal of Business Management, 5(5), 1871-1879.

[10] Publications: banglaesh bank. (n.d.). Retrieved from bangladesh Bank: https://www.bb.org.bd/pub/publictn.php

[11] Regulations and guidelines: bangladesh bank. (n.d.). Retrieved from bangladesh bank: https://www.bb.org.bd/aboutus/regulationguideline/guidelist.p hp. 